\title{
A Factor Analysis of Motivation-Behavior Affecting Factors Among Chinese College-English Learners
}

\author{
Hongyi Zhao ${ }^{1} \&$ Shaoyun Long ${ }^{1}$ \\ ${ }^{1}$ Foreign Languages College, Jiangxi Normal University, Nanchang, China \\ Correspondence: Hongyi Zhao, 99\#Ziyang Road, Foreign Languages College, Jiangxi Normal University, \\ Nanchang, Jiangxi Province, China. E-mail: 605608497@qq.com
}

Received: October 10, 2019 Accepted: November 4, 2019 Online Published: November 14, 2019

doi:10.5539/ells.v9n4p63 URL: https://doi.org/10.5539/ells.v9n4p63

\begin{abstract}
Based on multiple dimensions, with a contemporary college students' self-built English learning questionnaire $(\mathrm{r}=$ 0.872 ) of 775 subjects from two universities, and with a stratified sampling (120) and optimal oblique rotation, this study found some main factors of college Non-English major students. Results show that factor composition as a whole has a unique representation law. This study provides targeted psychological guidance for students to enhance their confidence and to improve their ability of meta-monitoring. Meanwhile, it has certain enlightenment for current college-English grading, classification and stratified teaching reform and improvement of students' interest in learning English.
\end{abstract}

Keywords: factor analysis, motivation behavior, multiple dimensions

\section{Introduction}

The construction of motivation-behavior in foreign language learning has always been one of the focuses in the psycholinguistic field. Since the 1990s, researchers on foreign language learning motivation have carried out comprehensive investigations of the motivation mode from the frameworks of mainstream motivational psychology, educational psychology, and cognitive psychology. The influential theoretical modes of foreign language learning motivation in this period mainly include: (1) Dôrnyei's (1998) three-level foreign language learning motivation theory; (2) Tremblay and Gardner's (1995) extended motivation theory; (3) Schumann's (1991) neurobiological mode. However, Gardner and Dôrnyei and other researchers put forward these modes in the 1980s and 1990s or in the background of a single or bilingual learning environment. These modes less involved the construction of the English learning motivation of Chinese college learners who take English as the major foreign language under the major college English teaching reform of the $21^{\text {st }}$ century.

Most of the studies on English learning motivation, such as Gao et al. (2002, 2003, 2008), Yang et al. (2004), Zhang (2002), Tang (2005), and Du (2004), were based on Gardener's single classical mode of sociolinguistics and cannot be separated from the relationship between motivation and the other factors affecting learning or between motivation and self-identity. These researches do not involve the construction of main factors of the learning motivation-behavior affecting factors from the perspective of ecological psychology.

The study on the construction of the learning motivation has a late start in China. Shi et al. (2002) and Liu (2002) discussed the affecting factors of learners' motivation from three aspects. Qin and Wen (2002) developed Tremblay and Gardner's extended mode of foreign language learning motivation-behavior (1995), and carried out a more in-depth research on LISREL model to explore the complex relationship between multiple motivation variables. Huang et al. (2005) conducted questionnaires to investigate the components of motivation of Chinese college students' English learning, and got 9 components concerning 4 levels. These researches revealed the inner relationship between motivation-behavior variables of Chinese college students in early $21^{\text {st }}$ century with a slightly wide sample range ( 2 provinces, 4 schools) and a large sample size (192 people), but modes in these studies over-emphasized the cognitive and emotional conditioning factors of language learners, and ignored the classroom environment factors and social environment factors as well as the realistic environment factors ,and self-decision-making ability of rational students. Otherwise, it is impossible to investigate the psychology and behavior of human beings if not under the unified system of man and environment for that environment is a factor that human beings must rely on, and these research paradigms are not ecological enough and cannot reproduce the present state of students' motivation-behavior in a natural and ecological way. 
Liu (2014), Long (2016) divided the factors affecting students' motivation into internal factors and external factors. Internal factors include the students' inner psychological traits, the students' self-awareness and the students' attributional tendencies. External factors include teachers, curriculum, and classroom environment. Wang (2016) discusses the factors affecting foreign language learning motivation from Dornyei's three-tier framework. Wang and Qin (2018) discussed the factors affecting motivation from four aspects. Han (2018) studied the influence of college students' learning motivation from the peer evaluation.

Based on the research paradigm of ecological psychology, this study will combine qualitative and quantitative research from a broader perspective of society, cognitive psychology, social cognition, social behavioral psychology, etc., to explore the ecological composition of factors influencing the English learning motivation behavior of non-English majors in universities which are undergoing the reform of college English curriculum in a deeper, hierarchical and systematic way, and prepare hypotheses and data for further discussion on the internal relationship between specific influencing factors.

\section{Ecological Psychology and Its Implications for the Research Paradigm of This Study}

The concept of ecology originated from the concept of "visual perception ecology" in The Ecological Approach to Visual Perception (James, 1986). Ecology emphasizes the extension of psychological research into the natural environment, opposes the opposition between subject and objective, and opposes the division or separation of cognition and direction. Ecological psychology provides people with a research orientation. It advocates the research principles of interaction, coordination, progress and symbiosis in methodology. Specifically, it abandons the single principle of causal experiment morphology and adopts the multi-method theory of the real life to examine the psychological characteristics (Sun, 2017). Therefore, from the perspective of discipline development, ecological psychology is a new orientation of contemporary psychology research mode.

\section{Mode Establishment of Foreign Language-Learning-Motivation Behavior}

Motivational behavior refers to a kind of behavior with which individuals are stimulated and maintained to work in a certain direction by the inter-coordination between individual internal requirements (instinct, need, drive) and external incentives (goal, reward and punishment) under their self-regulation (Gardner \& Tremblay, 1994). Motivation behavior includes effort and is the behavioral expression of motivation beliefs. According to the concept of motivation behavior, I holds the view that motivation-behavior of foreign language learning refers to a kind of behavior that individuals are stimulated and maintained to work in a certain positive direction by the inter-coordination between individual internal requirements to learn English and external incentives under their self-regulation, and it mainly includes three behavioral expressions: initiative to learn foreign language, effort toward foreign language learning and perseverance to learn foreign language.

Since the late 1990s, more new motivation factors have been introduced in the field of psychology by extending the motivation perspectives (Crookes et al., 1991; Dornyei, 1994; Noels, 2001; Oxford et al., 1994; Schmidt et al., 1996; Williams et al., 1997). In summary, the major motivation factors identified in psychology and applied linguistics are as follows: cognitive need and emotional need (Ausubel, 1968; Maslow, 1970), expectation and potency (Bandura, 1993 Schumt, 1991; Vroom 1964 ), goal orientation (Ames, 1992; Pintrich, 2000), attribution of result (Weiner, 1979; Platt, 1988), learning goal (Deci, 1992; Gardner, 1985; Wen et al., 1997), self-esteem (Clement et al., 1994; Horwitz, 1991) and effort (Gardener, 1985).

Based on the previous studies and Qin and Wen's (2002) identification and classification of motivation components, this research forms an ecological construction mode of motivation-behavior factors in foreign language learning (see Figure 1). Specifically, the mode also includes some types of motivational components, such as individual needs, motivation-premise, emotional intermediary, cognitive intermediary, motivation-behavior and learning outcomes. However, the individual needs are composed of language attitudes and future needs of language profession. Motivation premises include past foreign language achievements, attribution of result and foreign language interests, but highlight the language learning strategies.

Emotional intermediary includes anxiety, self-efficacy and self-confidence. Cognitive intermediary includes potency, learning goal and the sense of subjectivity rather than goal orientation. Emotional intermediary and cognitive intermediary play a regulatory role in the relationship between motivation-premise and motivation-behavior. Learning outcomes are divided into cognitive outcomes and emotional outcomes. Motivation-behavior here specifically includes: attention to the goal; initiative to pursue the goal; sustainability of pursuing the goal; effort toward the goal; time spent in pursuing the goal and other factors which makes an effect on learning outcomes. 


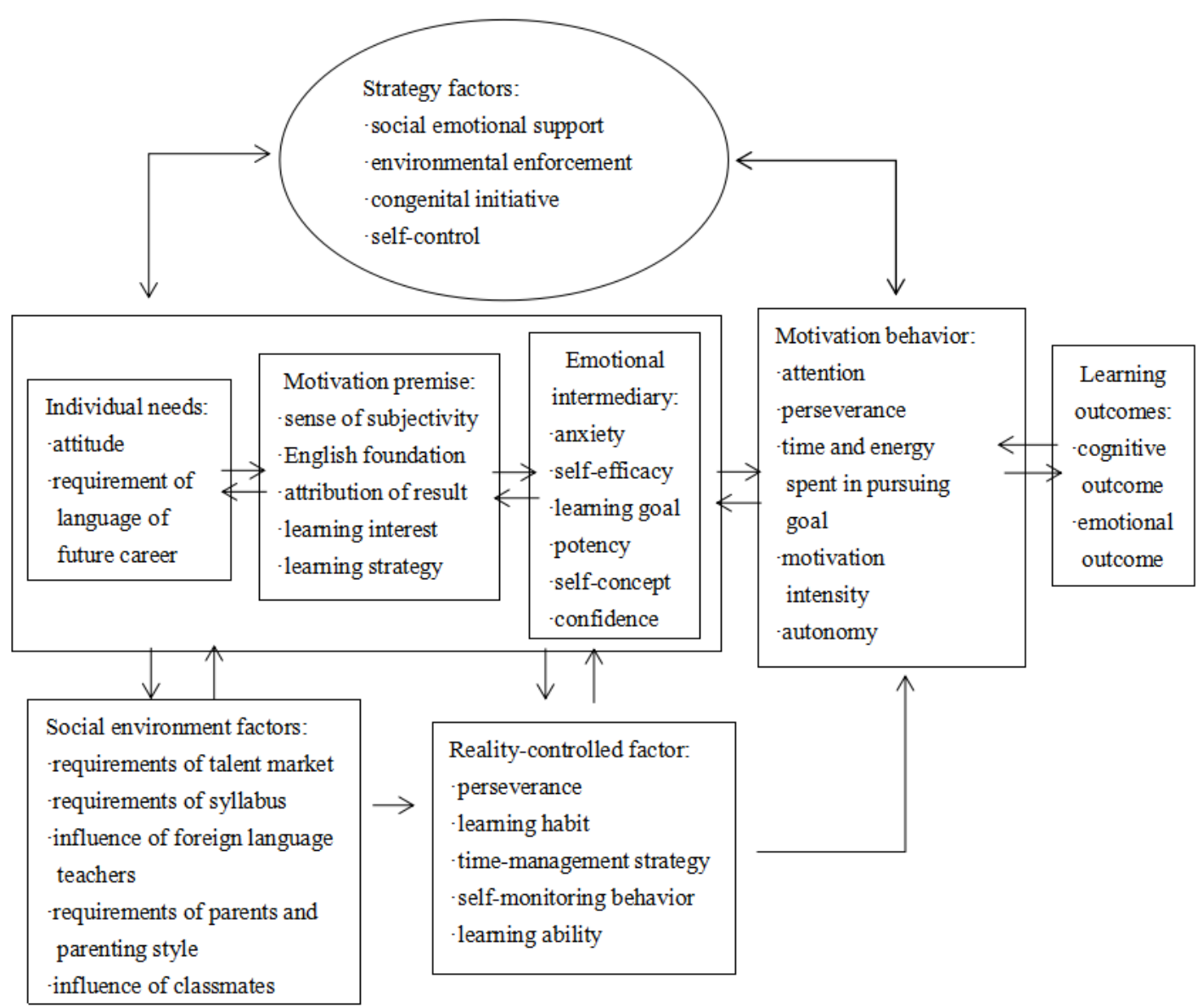

Figure 1. Ecological construction mode of motivation-behavior factors in foreign language learning

This study differs in that the mode accommodates three additional factors: social and environmental factors, reality-controlled factor, strategy factors and this study assumes that these factors work together to influence the motivation-behavior of contemporary Chinese college students.

The difference and the main focus of the research lie in the combination of research methodology of ecological psychology. It explores the value orientation of contemporary college students in foreign language learning and the self-regulation ability and self-management ability of themselves in the real world from the perspectives of cognition, social psychology and social cognition, social behavior psychology, and so on. And this study also explores the strategies adopted by college students in dealing with society, themselves and the conflicts between society and foreign language learning.

In this study, various factors mentioned above are integrated into 5 dimensions: cognition, emotion, social environment, reality-controlled factor, strategy. A view from the social cognitive school emphasizes that the social emotional support from others (such as sincere love, respect and encouragement) and the stimulation and reinforcement of the external environment (e.g., Their achievement is recognized) will affect the performance of motivation-behavior.

Studies of James Connell, Richard Ryan et al. (1991) have shown that students' learning motivation will be greatly improved when the teacher gives students more chance to make decisions or control the learning process autonomously.

Psychologist Rick (1988) believes that the function of thinking has a great effect on the stimulation of motivation. Through the intervention study of students' learning motivation, Psychologist Mills and Ryan (2007) concluded that all students, both normal and marginal, have a central mental health factor - a positive psychological potential (including congenital self-esteem and learning motivation). Students will be more willing to learn when they establish good relationships with others or when teachers teach them some skills of reflecting their own 
thinking.

On the basis of a comprehensive literature analysis of the theoretical framework of 13 motivational theoretical constructs (such as expectation-value theory, goal theory, self-determination theory, needs theory, balance theory, reinforcement theory, Tremblay and Gardner's (1995) extended motivation theory, Schumann's neurobiological mode, etc.), Dôrnyei (1989) comprehensively organized the variables related to foreign language learning motivations in seven dimensions.

Liu (2002) argues that there are many factors that affect the motivation of foreign language learning and the relationship among these factors is complex, but he only discusses the motivation-behavior affecting factors from the aspects of cognitive factors, emotional factors and social environmental factors. The first three factors of this study are based on the above-mentioned dimensions and basically contain all the major factors in each dimension. At the same time, attribution factor, learning goal factor, learning strategy factor and English foundation factor are added to cognitive factors.

College English teaching is currently entering a professional, humane, personalized period. It is the consensus of teaching researchers to undertake hierarchical teaching, classified teaching and graded teaching according to students' different learning strategies, different learning styles and different learning motivations. At present, CET4 is uncoupled from academic degree in most colleges. Allowing students to pre-select courses, teachers and learning environment will definitely have an impact on English learning. At the same time, students also have their own different learning motivation.

How to better stimulate college students' deep intrinsic learning motivation in this new background, and people need to analyze the construction of factors affecting English learning motivation of non-English majors in colleges in order to systematically and profoundly give targeted psychological counseling to students and guide them to enhance their confidence and meta-monitoring ability to better improve their academic level.

\section{Research Methodology}

\subsection{Research Questions}

1) Whether these affecting factors can make up a Motivation-behavior mode, if so, what it is?

2) Are these all factors affecting students' motivation behavior?

3) What are the main factors affecting students' motivation behavior?

\subsection{Participants}

In 2018, the author randomly selected 120 students from a group of 775 college students of two colleges (one is normal college, another is college of science and technology) including 456 first-year students (non-credit system, majors: 190 students majoring in life science, 66 majoring in bioengineering, 150 in Chinese, 50 in mathematics) and 319 sophomores (credit system, majors: law, politics, physics, chemistry, electrical information, business administration). In general, there are 49 sophomore students and 71 first-year students.

\subsection{Research Instruments}

\subsubsection{Factors Affecting Motivation Behavior}

According to previous studies, the affecting factors of motivation-behavior selected in this study are: (1) cognitive factors (including self-concept, self-efficacy, potency, sense of subjectivity, attribution, learning goal, learning strategy, English foundation); (2) emotional factors (including interest, attitude, needs, confidence and anxiety); (3) social environmental factors (including the requirements of the talent market, the requirements of the syllabus, the influence of the foreign language teacher, the requirements of the parent, the influence of classmates); (4) strategy factors (including socioemotional support, environmental strengthening, congenital initiative, self-control and thinking function); (5) reality-controlled factor (including learning habits, time management, self-monitoring, learning ability, perseverance), see Table 1. 
Table 1. Factor loading and factor composition of affecting factors

\begin{tabular}{|c|c|c|}
\hline Factor category & Description of potential variable by dominant variable & Factor loading \\
\hline \multirow[t]{10}{*}{ cognition } & $\begin{array}{l}\text { 1. [self-concept] } \mathrm{x}_{1} \text { : I have no advantage in learning foreign language [recognition of } \\
\text { advantage and disadvantage] }\end{array}$ & 0.679 \\
\hline & $\begin{array}{l}\text { [self-concept] } \mathrm{x}_{2} \text { : My foreign language learning is a failure [judgment of success and } \\
\text { failure] }\end{array}$ & 0.702 \\
\hline & $\begin{array}{l}\text { [self-concept }] \mathrm{x}_{3} \text { : Foreign language learning to some extent weaken my self-esteem } \\
\text { [recognition of the increase and decrease of self-esteem] }\end{array}$ & 0.655 \\
\hline & 2. [self-efficacy] $\mathrm{x}_{4}$ : I want to learn, but I can't learn well & 0.878 \\
\hline & $\begin{array}{l}\text { 3. [potency] } \mathrm{x}_{5} \text { : Learning foreign language well is a kind of burden. It's not worth wasting } \\
\text { too much time in it. }\end{array}$ & / \\
\hline & 4. [sense of subjectivity] $\mathrm{x}_{6}:$ Foreign language learning mainly depends on teachers & / \\
\hline & $\begin{array}{l}\text { 5. [tendency of attribution] } \mathrm{x}_{7} \text { : When I failed in English exam, I always think it is due to the } \\
\text { influence of teachers, environment and emotion (M) [external attribution] }\end{array}$ & / \\
\hline & 6. [learning goal $\mathrm{x}_{8}:$ My learning goal is not clear $(\mathrm{M})$ & / \\
\hline & 7. [learning strategy] $\mathrm{x}_{9}$ : I have no foreign language learning method (M) & / \\
\hline & $\begin{array}{l}\text { 8. [English foundation] } \mathrm{x}_{10} \text { : My English foundation is bad. I can't make a progress though I } \\
\text { am hardworking }(\mathrm{M})\end{array}$ & 0.832 \\
\hline \multirow[t]{5}{*}{ emotion } & 9. [interest $] \mathrm{x}_{11}: \mathrm{I}$ have on interest in learning English $(\mathrm{M})$ & 0.534 \\
\hline & 10. [attitude] $\mathrm{x}_{12}$ : I am lazy in thinking and doing $(\mathrm{M})$ & 0.699 \\
\hline & 11. [needs] $\mathrm{x}_{13}: \mathrm{I}$ have no needs in learning English $(\mathrm{M})$ & / \\
\hline & 12. [confidence] $\mathrm{x}_{14}$ : I always think that I can't learn English well (M) & 0.852 \\
\hline & 13. [anxiety] $\mathrm{x}_{15}: \mathrm{I}$ always worry that I can't learn English well & 0.820 \\
\hline \multirow[t]{5}{*}{ Social environment } & $\begin{array}{l}\text { 14. [social environment factor } \mathrm{x}_{16} \text { : I feel that the requirements of foreign language in } \\
\text { society is becoming higher and higher }(\mathrm{M}) \text { [requirements of talent market] }\end{array}$ & / \\
\hline & $\begin{array}{l}\text { [social environment factor] } \mathrm{x}_{17} \mathrm{I} \text { feel that the requirements of syllabus is becoming higher } \\
\text { and higher [requirements of syllabus] }\end{array}$ & I \\
\hline & $\begin{array}{l}\text { [social environment factor] } \mathrm{x}_{18} \text { : I feel that the care and encouragement from teacher is } \\
\text { becoming more and more [influence of foreign language teachers] }\end{array}$ & 0.875 \\
\hline & $\begin{array}{l}\text { [social environment factor] } \mathrm{x}_{19} \text { : I receive higher expectation from parents as well as more } \\
\text { encouragement [requirements of parents and parenting style] }\end{array}$ & 0.629 \\
\hline & $\begin{array}{l}\text { [social environment factor] } \mathrm{x}_{20} \text { : I want to improve my English because my classmates } \\
\text { around me learn English better and better [influence of classmates] }\end{array}$ & 0.786 \\
\hline Reality-Controlled & 15. [perseverance] $\mathrm{x}_{21}: \mathrm{I}$ just lack perseverance in learning English (M) & 0.848 \\
\hline \multirow[t]{4}{*}{ factor } & 16. [learning habit] $\mathrm{x}_{22}$ : I have poor learning habits since I was young (M) & / \\
\hline & 17. [time-management strategy] $\mathrm{x}_{23}$ : I can't make good use of spare time (M) & 0.845 \\
\hline & 18. [self-monitoring behavior] $\mathrm{x}_{24}$ : I can't carry out the plan I have already made (M) & 0.829 \\
\hline & $\begin{array}{l}\text { 19. [learning ability] } \mathrm{x}_{25} \text { : I have poor English learning ability (memory, comprehension and } \\
\text { reasoning) (M) }\end{array}$ & 0.538 \\
\hline \multirow[t]{5}{*}{ strategy } & $\begin{array}{l}\text { 20. [social emotional support] } \mathrm{x}_{26} \text { : It is helpful for me to receive the sincere care and } \\
\text { encouragement from my teachers or classmates }\end{array}$ & 0.489 \\
\hline & $\begin{array}{l}\text { 21. [environment enhancement] } \mathrm{x}_{27} \text { : I am eager to receive timely approval and } \\
\text { encouragement when I make a progress }\end{array}$ & 0.766 \\
\hline & $\begin{array}{l}\text { 22. [Congenital initiative] } \mathrm{x}_{28} \text { : If people have a positive and reliable goal, they will devote } \\
\text { themselves into the task }\end{array}$ & 0.770 \\
\hline & $\begin{array}{l}\text { 23. [self-control] } \mathrm{x}_{29} \text { : I will learn harder if teachers give more chance to decide my own } \\
\text { learning progress autonomously }\end{array}$ & 0.670 \\
\hline & $\begin{array}{l}\text { 24. [thinking function] } \mathrm{x}_{30} \text { : I insist on the view that people will behave positively if they } \\
\text { have optimistic thinking style }\end{array}$ & 0.685 \\
\hline
\end{tabular}

\subsubsection{Questionnaire}

The Cronbach $\alpha$ coefficient of the three categories as a whole in the questionnaire reached 0.872 , indicating that the selection of these multidimensional factors had a high internal consistency.

\subsubsection{Scoring Method}

The questionnaire uses five-points scoring method: from A (5 points) to $\mathrm{E}$ (1 point) while from A (1 point) to $\mathrm{E}$ (5 points) for reverse question (M). The higher the score, the deeper the influence is. 


\subsection{Research Procedures}

\subsubsection{Examining the Suitability of the Data to Do Factor Analysis}

The questionnaire data are entered into SPSS 11.5 for KMO and Bartlett's test. The results show that for the three categories as a whole, 4 main factors were found through only twice factor analyses, KMO value is from 0.792 to 0.832 to 0.821 . “... These factors contain a small number of variables, so it is more appropriate to delete them. There is a need for a further factor analysis because the factor structure has changed after the deletion of factors" (Qin, 2003, p. 65). The following seven factors were deleted in the first factor analysis: $\mathrm{x}_{13}(0.731)$ and $\mathrm{x}_{5}(0.607)$ as factor $5, \mathrm{x}_{16}(0.821)$ and $\mathrm{x}_{17}(0.652)$ as factor $6, \mathrm{x}_{7}(0.845)$ and $\mathrm{x}_{6}(0.719)$ as factor 7 and $\mathrm{x}_{22}(0.500)$ as factor 8 while $\mathrm{x}_{8}(0.656)$ and $\mathrm{x}_{9}(0.570)$ as main factor 5 is deleted in the second factor analysis. All significance values here are 0.000 , indicating that the data are suitable to do factor analysis.

\subsubsection{Determining the Number of Factors}

Using the principal factor analysis method and the promax rotation method, the scree plot of factor characteristics is formed and four factors are finally determined (see Figure 2). Only the report table of factor analysis of all subjects and the scree plot of factor characteristics are provided here to support this research.

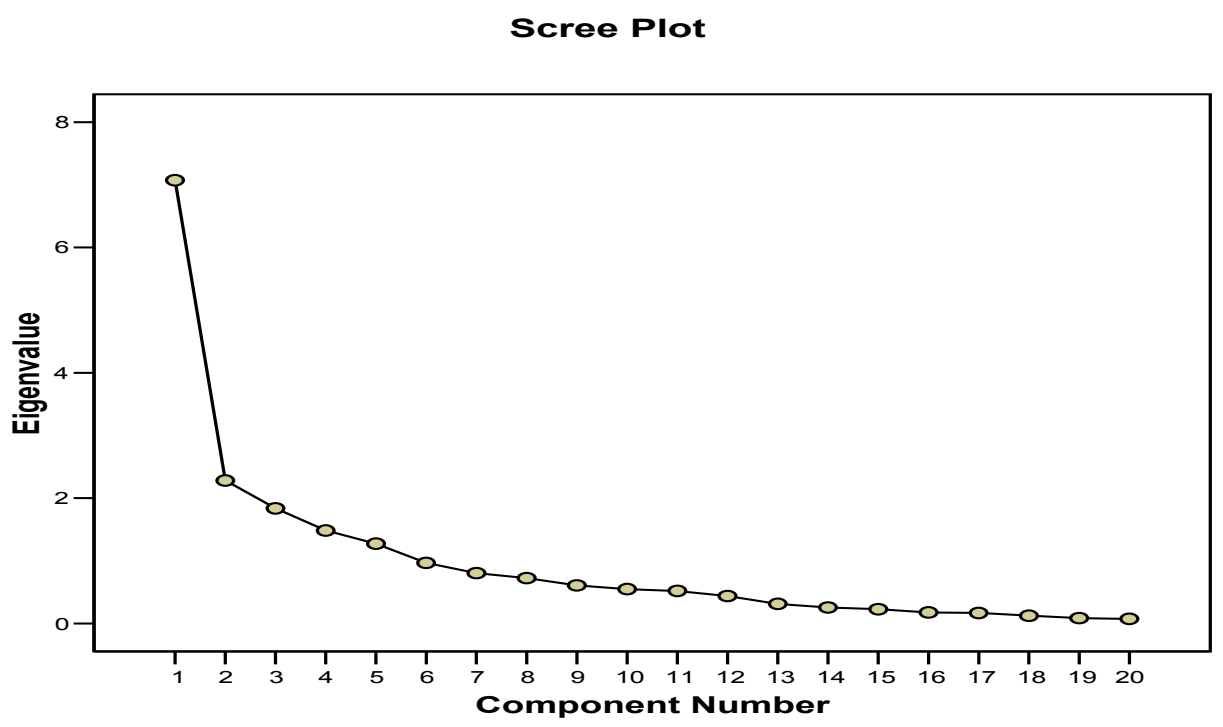

Figure 2. The scree plot of factor characteristics

\subsubsection{Naming and Explaining Factors}

This research names each main factor on the basis of questionnaire design principle and various characteristics of college students. Specific details of factor naming are in Table 2. 
Table 2. Factor analysis of students

\begin{tabular}{|c|c|c|c|c|}
\hline Factoring naming & Corresponding items & $\begin{array}{l}\text { Factor } \\
\text { loading }\end{array}$ & Eigenvalues & $\begin{array}{l}\% \text { of } \\
\text { variance }\end{array}$ \\
\hline \multirow[t]{9}{*}{ W1: emotional reality } & $\mathrm{x}_{4}$ : I want to learn, but I can't learn well & 0.878 & 5.774 & 30.350 \\
\hline & $\begin{array}{l}\mathrm{x}_{10} \text { : My English foundation is bad. I can't make a progress though I } \\
\text { am hardworking }(\mathrm{M})\end{array}$ & 0.832 & & \\
\hline & $\mathrm{x}_{14}$ : I always think that I can't learn English well (M) & 0.825 & & \\
\hline & $\mathrm{x}_{15}$ : I always worry that I can't learn English well & 0.820 & & \\
\hline & $\begin{array}{l}\mathrm{x}_{2} \text { : My foreign language learning is a failure [judgment of success } \\
\text { and failure] }\end{array}$ & 0.702 & & \\
\hline & $\begin{array}{l}\mathrm{x}_{1}: \text { I have no advantage in learning foreign language [recognition } \\
\text { of advantage and disadvantage] }\end{array}$ & 0.679 & & \\
\hline & $\begin{array}{l}\mathrm{x}_{3} \text { : Foreign language learning to some extent weaken my } \\
\text { self-esteem [recognition of the increase and decrease of } \\
\text { self-esteem] }\end{array}$ & 0.655 & & \\
\hline & $\begin{array}{l}\mathrm{x}_{25} \text { : I have poor English learning ability (memory, comprehension } \\
\text { and reasoning) (M) }\end{array}$ & 0.538 & & \\
\hline & $\mathrm{x}_{11}: \mathrm{I}$ have on interest in learning English $(\mathrm{M})$ & 0.534 & & \\
\hline \multirow[t]{4}{*}{ W2: reality cognition } & $\mathrm{x}_{23}:$ I can't make good use of spare time $(\mathrm{M})$ & 0.854 & 3.85 & 11.618 \\
\hline & $\mathrm{x}_{21}$ : I just lack perseverance in learning English (M) & 0.848 & & \\
\hline & $\mathrm{x}_{24}$ : I can't carry out the plan I have already made (M) & 0.829 & & \\
\hline & $\mathrm{x}_{12}: \mathrm{I}$ am lazy in thinking and doing $(\mathrm{M})$ & 0.699 & & \\
\hline \multirow[t]{4}{*}{$\begin{array}{l}\text { W3: strategy } \\
\text { cognition }\end{array}$} & $\begin{array}{l}\mathrm{x}_{28} \text { : If people have a positive and reliable goal, they will devote } \\
\text { themselves into the task }\end{array}$ & 0.770 & 2.973 & 9.454 \\
\hline & $\begin{array}{l}\mathrm{x}_{27}: \text { I am eager to receive timely approval and encouragement } \\
\text { when I make a progress }\end{array}$ & 0.766 & & \\
\hline & $\begin{array}{l}\mathrm{x}_{30} \text { : I insist on the view that people will behave positively if they } \\
\text { have optimistic thinking style }\end{array}$ & 0.685 & & \\
\hline & $\begin{array}{l}\mathrm{x}_{29} \text { : I will learn harder if teachers give more chance to decide my } \\
\text { own learning progress autonomously }\end{array}$ & 0.670 & & \\
\hline \multirow[t]{4}{*}{$\begin{array}{l}\text { W4: social emotional } \\
\text { support }\end{array}$} & $\begin{array}{l}\mathrm{x}_{18} \text { : I feel that the care and encouragement from teacher is } \\
\text { becoming more and more [influence of foreign language teachers] }\end{array}$ & 0.875 & 3.066 & 7.605 \\
\hline & $\begin{array}{l}\mathrm{x}_{20} \text { : I want to improve my English because my classmates around } \\
\text { me learn English better and better [influence of classmates] }\end{array}$ & 0.786 & & \\
\hline & $\begin{array}{l}\mathrm{x}_{19} \text { : I receive higher expectation from parents as well as more } \\
\text { encouragement [requirements of parents and parenting style] }\end{array}$ & 0.629 & & \\
\hline & $\begin{array}{l}\mathrm{x}_{26}: \text { It is helpful for me to receive the sincere care and } \\
\text { encouragement from my teachers or classmates }\end{array}$ & 0.489 & & \\
\hline
\end{tabular}

\section{Discussion}

\subsection{Factors Construction}

It can be seen from Table 2 that the factors construction of the overall motivation-behavior of the three categories of students are basically consistent with the original hypothetical mode. However, there are some factors are missing: emotion, learning goals in cognitive intermediary, confidence, potency, sense of subjectivity in motivation premise, attribution, learning strategy, learning habits and requirements of the talent market and requirements of syllabus. These factors are deleted by twice factor analyses because variables they contain are less than 3. However, these factors have high factor loading ranging from 0.500 to 0.878 , which indicates that the original variable is highly correlated with the common factor. Combining with the fact mentioned above, mean value and author's understanding of college students, English learning situation of contemporary college students can be inferred: All of them show clear learning purposes, strong confidence and better potency, knowing how to attribute, having a full psychological preparation for the requirements of the talent market and having a better expectation of the improvement of the requirements of syllabus. They also have a strong sense of subjectivity, good learning strategies and learning habits.

\subsection{Interpretation of Factors}

As for the three categories as a whole (see Table 2), the mentality of learning English of contemporary college students can be seen in the information of 4 main factors. They can clearly recognize their own shortcomings, such as failing to make good use of spare time, lacking perseverance and self-monitoring ability. They lack 
confidence and often lost themselves because they think they have no advantage in learning English. Therefore, they expect teachers, parents and classmates to give more encouragement and warning when they are not rational enough and give timely encouragement and care when they make progress. They believe that they have a natural initiative, and hope that teachers can give themselves more autonomy and timely help. They also believe that optimistic attitude will produce positive performance.

\section{Research Implications}

The difference of this study lies in the following three major factors: (1) social environmental factors; (2) reality-controlled factor; (3) strategic factors, while it follows Gardner's single classical mode of social linguistics.

\subsection{Implications to the Research Object}

First, it is to study the psychology and behavior of human beings not simply from the view of human, but under the unified system of human and environment.

This study includes factors related to educational situation (including learning environment, classroom environment and school environment) and other influential individual anthropological factors (such as family, parents, classmates, etc.) in combination with practical dimensions of language curriculum and talent market requirements.

\subsection{Implications to the Research Method}

Ecological psychology advocates doing research in the real environment.

This study adds the reality-controlled factors of motivation (including motivation, learning habits, time-management strategy, self-monitoring behavior, learning ability) to the motivation affecting factors in Qin Xiaoqing's motivational mode. At the same time, this study adds strategy factors (including social emotional support, autonomous control, environmental strengthening, thinking function, innate initiative) which stimulate and maintain motivation to the motivation factors in original mode, so that learners' common performance of time management and self-control of realistic environmental factors as well as the strategy factors are naturally and ecologically generated in the construction of learners' motivation.

\section{Innovation and Development of The Research}

The significance of this study is that the research mode accommodates three other factors (social environmental factors, reality-controlled factor and strategy factor) on the basis of Gardener's single classical model of sociolinguistics. This study realizes the change of the research object. It investigates psychology and behavior of human beings not from the perspective of human beings, but under the unified system of human and environment. The research gives more attention to factors related to educational environment (including learning environment, classroom environment and school environment) and other influential individual-related dimensions (such as family, parents, classmates, etc.). In the research, language syllabus is combined with the requirements of talent market, which promotes the true realization of the proposition: Do research in the real environment.

Based on Qin Xiaoqing's motivation mode, this study adds reality-controlled factor (including perseverance, learning habits, time-management strategy, self-monitoring behavior and learning ability). Otherwise, this study adds strategy factors (including social emotional support, autonomous control, environmental strengthening, thinking function, innate initiative) which stimulate and maintain motivation to the motivational factors in original mode. Such a fresh and ecological constitution of motivation reflects naturally the state of the motivation-behavior of contemporary college students in English learning, which has an enlightening significance for the stimulation and maintenance of motivation-behavior and college English teaching reform.

The unique part of this study is to employ the methods and ideas of ecological psychology research, and study the value orientation of contemporary college students in English learning as well as the self-regulation and self-management ability they show in realistic society from several perspectives. Contemporary college students are experiencing professional, humane and personalized college English teaching reform. Their English learning motivations have differentiated in rationality and irrationality. In addition, this study explores the state and the strategies adopted by more intellectual and rational college students in dealing with society, themselves and the conflicts between society and foreign language learning.

\section{Conclusion}

Through the empirical analysis and research, this paper draws the following conclusions. The main factors that affect the overall college students includes lacking a strong sense of self-efficacy, lacking a good English 
foundation, lacking self-confidence, lacking a high earning interest, having a high level of anxiety and a low sense of self-concept.

Based on the multidimensional perspective and ecological psychology research methods and ideas, this study compiles questionnaire, collects and analyzes statistics according to the realistic state of college English learning from the perspective of cognitive psychology, and highlights the construction of the main factors affecting the learning motivation-behavior of non-English majors. Then, the research makes a preliminary analysis and discussion on the factors obtained according to the author's understanding of college students so as to give some inspiration to English teaching and education.

This study basically reaches the original intention, but the sample size is small. Extraction of sub-factor, the further confirmation of common factors, the framework of the constitution of affecting factors still need to be analyzed objectively through a questionnaire of a larger sample.

\section{Reference}

Ames, C. (1992). Classrooms, Goals, Structures, and Student Motivation. Journal of Educational Psychology, 84, 267-271. https://doi.org/10.1037//0022-0663.84.3.261

Ausubel, D. (1968). Educational Psychology: A Cognitive View. New York: Holt, Rinehart \&Winston.

Bandura, A. (1993). Perceived Self-efficacy in Cognitive Development and Functioning. Educational Psychologist, 28, 117-148. https://doi.org/10.1207/s15326985ep2802_3

Clement, R., Dornyei, Z., \& Noels, K. (1994). Motivation, Self-confidence, and Group Cohesion in the Foreign Language Classroom. Language Learning, 44, 417-448. https://doi.org/10.1111/j.1467-1770.1994.tb01113.x

Clifford, M. M. (1984). Thoughts on a Theory of Constructive Failure. Educational Psychology, 19, 108-120. https://doi.org/10.1080/00461528409529286

Connell, J. P., \& James, G. W. (1991). Competence, Autonomy, and Relatedness: A Motivational Analysis of Self-System Processes. In M. Gunnarand \& A. Sroufe (Eds.), Minnesota Symposium on Child Psychology (vol.23, pp. 43-77). Hillsdale, N.J.: Lawrence Erlbaum Associates.

Crookes, G., \& Schmidt, R. W. (1991). Schmidt. Motivation: Reopening the Research Agenda. Language Learning, 41, 469-512. https://doi.org/10.1111/j.1467-1770.1991.tb00690.x

Deci, E. (1992). The Relation of Interest to the Motivation of Behavior: A Self-determination Theory Perspective. In K. A. Renninger, S. Hidi \& A. Krapp (Eds.), The Role of Interest in Learning and Development. Hillsdale, N.J.: Lawrence Erlbaum.

Deci, E. L., \& Ryan, R. M. (1985). Intrinsic Motivation and Self-Determination in Human Behavior. New York: Plenum Press. https://doi.org/10.1007/978-1-4899-2271-7

Deci, E. L., \& Ryan, R. M. (1985a). The General Causality Orientations Scale: Self-determination in Personality. Journal of Research in Personality, 19, 109-134. https://doi.org/10.1016/0092-6566(85)90023-6

Dornyei, Z. (1994). Motivation and Motivating in the Foreign Language Classroom. Modern Language Journal, l78, 273-284. https://doi.org/10.1111/j.1540-4781.1994.tb02042.x

Dornyei, Z., \& Csizer, K. (1998). Ten Commandants for Motivating Language Learners: Results of an Empirical Study. Language Teaching Research, 2(3), 203-229. https://doi.org/10.1191/136216898668159830

Du, F. X. (2004). Learning Motivation and College Students' English Writing. Foreign Languages and Their Teaching, 28-31.

Gao, Y. H., \& Zhao, Y. (2003). The Relationship between English Learning Motivation and Motivation Intensity-A Quantitative Study of Undergraduates. Foreign Language Research, 60-64.

Gao, Y. H., Zhao, Y., Cheng, Y. et al. (2002). The Relationship between English Learning Motivation Types and Self-identity Changes in Undergraduates. Foreign Language Teaching Abroad.

Gao, Y. H., Zhao, Y., Cheng, Y. et al. (2003). The types of English learning motivation of Chinese College Students. Modern Foreign Language.

Gao, Y. H., Zhao, Y., Cheng, Y. et al. (2003a). The change of College Students' English Learning Motivation and Self-identity. Foreign Languages and Their Teaching.

Gardner, R. C. (1985). Social Psychology and Language Learning: The Role of Attitudes and Motivation. 
London: Edward Arnold.

Gardner, R. C. (1992). Second Language Learning in Adults: Correlates of Proficiency. Applied Language Learning, 2, 1-28.

Horwitz, E. (1991). Preliminary Evidence for the Reliability and Validity of a Foreign Language Anxiety Scale. In E. Horwitz \& D. Young (Eds.), Language Anxiety: From Theory and Research to Class-room Implications. Englewood Cliffs, N. J.: Prentice-Hall Inc.

Huang, H. A., \& Wen, W. P. (2005). Empirical Study on the Factors Affecting English Learning Motivations of Non-English Majors. Foreign Language Teaching Abroad.

James J. G. (1986). The Ecological Approach to Visual Perception. Mahwah, Lawrence Erlbaum Associates.

Liu, D. L. (2002). Some Reflections on Motivation in Foreign Language Teaching. Foreign language Education, 58-61.

Liu, L., \& Gao, Y. H. (2008). English Learning Motivation and Self-identity Changes-A Survey of the Sophomores of English Majors. Foreign Language in China.

Liu, W. (2014). Factors Affecting English Learning Motivation. Inner Mongolia Education.

Long, J. S. (2016). Analysis on the Influencing Factors of English Learning Motivation. Journal of Kaifeng Institute of Education.

Maslow, A. H. (1970). Motivation and Personality. New York: Harper \& Row.

Mills, R. C., Richard, M., Ryan, J., \& David, C. (2007). Mindfulness: Theoretical Foundations and Evidence for its Salutary Effects. Psychological Inquiry, 18(4), 211-237. https://doi.org/10.1080/10478400701598298

Nicholls, J. G. (1984). Achievement Motivation: Conceptions of Ability, Subjective Experience, Task Choice, and Performance. Psychological Review, 91(3), 328-346. https://doi.org/10.1037//0033-295X.91.3.328

Noels, K. A. (2001). Learning Spanish as a Second Language: Learners' Orientations and Perceptions of Their Teachers' Communication Style. Language Learning, 51, 107-144. https://doi.org/10.1111/0023-8333.00149

Oxford, R. L., \& J. Shearin. (1994). Language Learning Motivation: Expanding the Theoretical Framework. Modern Language Journal, 78, 12-28. https://doi.org/10.1111/j.1540-4781.1994.tb02011.x

Pintrich, P. R. (2000). Multiple Goals, Multiple Path-ways: The Role of Goal Orientation in Learning and $\begin{array}{llll}\text { Achievement. Journal of Educational Psychology, 92, 544-555. } & \text { of }\end{array}$ https://doi.org/10.1037//0022-0663.92.3.544

Platt, C. W. (1988). Effects of Causal Attributions for Success on First-term College Performance: A Covariance Structure model. Journal of Educational Psychology, 80, 569-578. https://doi.org/10.1037/0022-0663.80.4.569

Qin, X. Q. (2003). Quantitative Data Analysis in Foreign Language Teaching Research. Wuhan: HUST Press.

Qin, X. Q. (2003a). A Study of Second Language Learning Motivation and Its Existing Problems. Foreign Language Education, 16-19.

Qin, X. Q., \& Wen, Q. F. (2002). The Intrinsic Structure of Non-English Majors' Motivation. Foreign Language Teaching and Research, 51-58.

Ryan, R. M. (1993). Agency and Organization: Intrinsic Motivation, Autonomy and the Self in Psychological Development. In J. Jacobs (Ed.), Nebraska Symposium on Motivation: Developmental Perspectives on Motivation (vol. 40, pp. 1-56). Lincoln, NE: University of Nebraska Press.

Schmidt, R., Boraie, D., \& Kassabgy, O. (1996). Foreign Language Motivation: Internal Structure and External Connections. In R. L. Oxford (Ed.), Language Learning Motivation: Pathways to the New Century. University to Hawaii at Manoa: Second Language Teaching \& Curriculum Center.

Shi, S. H. et al. (2002). A Study on Middle School Students' Learning Motivation and Its Influencing Factors. Education Research.

Suarez, E. M. (1988). A Neocognitive Dimension. The Counseling Psychologist, 16(2), 239-244. https://doi.org/10.1177/0011000088162003

Tang, W. L. (2005). An Investigation and Analysis of the Influence of Motivational Factors on Oral English Learning. Foreign Language Education, 65-68. 
Tremblay, P., \& Gardner, R. (1995). Expanding the Motivation Construct in Language Learning. Modern Language Journal, 79, 505-520. https://doi.org/10.2307/330002

Vroom, V. (1964). Work and Motivation. New York: Wiley.

Wang, Y. L. (2016). Factors Affecting the Motivation of Foreign Language Learning and Its Implications for College English Teaching. Journal of Changchun Institute of Education.

Wang, Y. J., \& Qin, X. T. (2018). Research on Student Subject Classification and Its Influencing Factors Based on Learning Motivation Perception-Based on the Evaluation of Colleges and Universities in Jiangsu Province. Journal of Yancheng Institute of Technology.

Weiner, B. (1979). A Theory of Motivation for Some Class-room Experiences. Journal of Educational Psychology, 71, 3-25. https://doi.org/10.1037//0022-0663.71.1.3

Wen, Q. F., \& Johnson, R. K. (1997). L2 Learner Variables and English Achievement: A study of Tertiary-Level English Majors in China. Applied Linguistics, 18, 27-48. https://doi.org/10.1093/applin/18.1.27

Williams, M., \& Burden, R. (1997). Psychology for Language Teachers. Cambridge: Cambridge University Press.

\section{Copyrights}

Copyright for this article is retained by the author, with first publication rights granted to the journal.

This is an open-access article distributed under the terms and conditions of the Creative Commons Attribution license (http://creativecommons.org/licenses/by/4.0/). 